\title{
Predominance of Giardia intestinalis assemblage B in diarrhoeic children in Sharkia, Egypt
}

\section{Original Article}

\author{
Ayman A. El-Badry ${ }^{1}$, Faten A. Mohammed ${ }^{2}$, Eman Abdul Gawad ${ }^{3}$ \\ ${ }^{1}$ Department of Microbiology-Medical Parasitology Section, College of Medicine, University \\ of Dammam, Dammam, Saudi Arabia \\ ${ }^{2}$ Parasitology Department, Faculty of Medicine, Zagazig University, Sharkia, Egypt \\ ${ }^{3}$ Laboratory of Molecular Medical Parasitology (LMMP), Medical Parasitology Department, \\ Kasr Al-Ainy Faculty of Medicine, Cairo University, Egypt
}

\begin{abstract}
Background: Giardia intestinalis (G. intestinalis) is one of the most common human enteric protozoa that infect Egyptian children, causing most of the diarrhoeic outbreaks worldwide. Identification of G. intestinalis assemblage is important because of its role in determining sources of infection, in understanding the ecological and clinical impact of giardiasis, and hence its management and control.

Objective: Study of this cross-sectional sample aimed to determine the genotypes of $G$. intestinalis isolated from the feces of diarrhoeic children attending outpatient clinic of Zagazig University hospital.

Subjects and Methods: A single fecal sample was collected from each child $(\mathrm{n}=126)$. All samples were subjected to microscopic examination by direct wet mount before and after formal- ethyl acetate concentration. Positive samples were amplified by nested PCR (nPCR) and sequenced for intra and inter assemblage identification targeting tpi gene.

Results: Microscopic examination revealed detection of $G$. intestinalis in 38 samples (30.2\%). In 36 (28.6\%) samples there was assemblage B predominance in 34 (94.4\%) isolates, among which 24 (70.6\%) were subgenotype BIV and 10 (29.4\%) were sub-genotype BIII. Only 2 (5.6\%) samples had assemblage A; all of them were AII subgenotype. All studied patient's demographic and clinical data showed no significant association with Giardia infection or prevailing Giardia assemblages.

Conclusion: G. intestinalis is the prevailing intestinal pathogen in diarrhoeic Egyptian children, with Giardia assemblage B predominance. These findings necessitate physicians' attention and further genetic studies in Egypt and other endemic areas targeting different genetic loci, with the inclusion of larger population samples. This will lead to a better understanding of the ecological and clinical impact of giardiasis, its management and control.
\end{abstract}

Key Words: Assemblage, genotyping, Giardia, nPCR, tpi gene.

Received: 15 February 2017, Accepted: 12 March 2017.

Corresponding Author: Faten A. Mohammed, Tel.: +20-10-2031-1001, E-mail: fatenmr@yahoo.

ISSN: 1687-7942, Vol. 10, No. 1 \& 2 .

\section{INTRODUCTION}

Giardiasis, an infection with $G$. intestinalis (synonyms: $G$. duodenalis, $G$. lamblia), is one of the most common intestinal protozoan present in humans, both in Egypt and worldwide ${ }^{[1,2]}$. Clinical presentations of giardiasis vary, ranging from asymptomatic infection to chronic symptomatic infection. Infected patients present with diarrhea, steatorrhea, flatulence, and malabsorption and/ or weight $\operatorname{loss}^{[3-5]}$. Giardiasis can affect all age groups; however, children are the most affected age group, for whom it can cause severe acute diarrhea that may in turn lead to malabsorption, malnutrition with growth impairment ${ }^{[6,4,5]}$.

The prevalence of human giardiasis varies from $2 \%$ in developed countries to $70 \%$ in developing countries ${ }^{[7]}$. In Egypt, prevalence of giardiasis is up to $48 \%{ }^{[8]}$, a fact that makes Egypt a hyperendemic region according to the World Health Organization (WHO) criteria ${ }^{[9]}$. However, its true prevalence is unknown.

G. intestinalis is classified into eight assemblages from A to $\mathrm{H}^{[10-13]}$. Determination of Giardia assemblages is needed to understand routes of transmission, epidemiology, and range of the host, in addition to study of outbreaks ${ }^{[14]}$. In a report from Egypt, El Tantawy and Taman ${ }^{[15]}$, reported the predominance of assemblage $\mathrm{B}$ over assemblage $\mathrm{A}$, and few mixed A and B. The aim of the present study was to update the understanding of the epidemiology of Giardia assemblages prevailing in children attending outpatient clinics of Zagazig University Hospital.

\section{MATERIALS AND METHODS}

Study type and populations: This cross-sectional study sample included 126 children (5 to 12 years old), 
suffering from diarrhea and/or other gastrointestinal symptoms, attending outpatient clinics of Zagazig University Hospital, Egypt.

Samples collection and processing: A single stool sample was collected from each diarrheic child attending the outpatient clinic. All collected samples were examined microscopically with iodine wet mount, after formalethyl acetate concentration at Parasitology Department Laboratory, Faculty of Medicine, Zagazig Unversity to detect $G$. intestinalis and other parasites. Part from each stool sample was freshly frozen at $-20^{\circ} \mathrm{C}$ for copro immuno-molecular assays at the Laboratory of Molecular Medical Parasitology (LMMP), Kasr Al-Ainy Faculty of Medicine, Cairo University.

Copro-PCR assay: All samples microscopically positive for $G$. intestinalis trophozoites and/or cysts were subjected to genomic DNA extraction using Favor Prep stool DNA isolation Kit (Favorgen Biotech corporation ping-Tung 908, Taiwan), according to the manufacturer's instructions. The extracted DNA was submitted to a nPCR procedure for amplification of a 530-bp region targeting the triosephosphate isomerase (tpi) gene, using AL3543 (19 bp): 5'-AAA TIA TGC CTG CTC GTC G-3' and AL3546 (19 bp): 5'-CAA ACC TTI TCC GCA AAC C-3 primers for first PCR, AL3544 (20 bp): 5'CCC TTC ATC GGI GGT AAC TT-3' and AL3545 (20 bp): 5'- GTG GCC ACC ACI CCC GTG CC-3 for $\mathrm{nPCR}$. The reaction mixture and conditions were performed according to Sulaiman et al. ${ }^{[16]}$ in a volume of $25 \mu \mathrm{l}$ containing $3 \mu \mathrm{l}$ of DNA extract for first PCR reaction or 1 $\mu \mathrm{l}$ of the second PCR reaction of the nPCR, $12.5 \mu$ master mix PCR kit (thermo scientific, UK, Lot no.\#K1081), $1 \mu \mathrm{l}$ of each forward and reverse primer, $0.1 \mu \mathrm{l}$ of Taq polymerase (Qiagen, Germany) and 7.4-9.4 $\mu \mathrm{l}$ ddH2O. PCR reactions were performed in Biometra thermal cycler (Tpersonal). The PCR amplification reactions for Giardia were performed in conditions consisting of $5 \mathrm{~min}$ at $95^{\circ} \mathrm{C}$ followed by 35 cycles of $45 \mathrm{sec}$ at $94^{\circ} \mathrm{C}, 45 \mathrm{sec}$ at $50^{\circ} \mathrm{C}, 60$ sec at $72^{\circ} \mathrm{C}$ and, finally, by $7 \mathrm{~min}$ at $72^{\circ} \mathrm{C}$. Positive control, negative control and blank containing sterile distilled water in place of template DNA were included for each reaction set. Amplified DNA fragments were analyzed by electrophoresis in a $1.5 \%(\mathrm{w} / \mathrm{v})$ agarose gel stained with ethidium bromide $(0.5 \mu \mathrm{g} / \mathrm{ml})$ and visualized under a UV light system ${ }^{[17]}$.

Sequencing: $\mathrm{nPCR}$ products were sequenced to determine Giardia assemblage. The amplified products were purified using Qiagen PCR purification kit (QIAGEN, Hilden, Germany) according to the manufacturer's instructions and visualized on $1.5 \%$ agarose gel electrophoresis. Purified nPCR products were sequenced with BigDye $\mathbb{R}$ Terminator v 3.1. Ready Reaction Cycle Sequencing Kit (Applied Biosystems, Foster City, CA, USA). Big Dye X purification kit (Applied Biosystems, Foster City, CA,USA) were used to clean post sequencing reaction products according to the manufacturer's instructions. DNA template sequencing was performed in both directions on an ABI Prism 310 genetic analyzer (Applied Biosystems, Foster City, CA,USA).

Statistical analysis: Data entry and analysis were performed using the statistical package for social sciences (SPSS) version 20. Mean \pm standard deviation were used for analysis of descriptive data, while frequencies were used to analyze qualitative data. Giardia infection was the dependent variable and chi-square test was used to assess its significance of association with the independent variables (demographic data and clinical symptoms).

Ethical considerations: Fecal samples were collected from children after informing their parents about the purpose of the study and informed consent was obtained from parents of all children included in the study.

\section{RESULTS}

G. intestinalis was detected in 38 samples $(30.2 \%)$. Among them 36 (28.6\%) samples were successfully amplified by nPCR and genotyped by sequencing using tpi gene (Fig. 1). Their age ranged from 5 to 12 years old with mean of $7.34 \pm 2.33$ without statistical significance $(P=0.96)$. Both Giardia assemblage B and A $(94.4 \%$ $[\mathrm{n}=34], 5.6 \%[\mathrm{n}=2]$, respectively) were detected. All assemblage A samples were AII while subgenotyping of assemblage B was BIII and BIV (29.4\% [ $\mathrm{n}=10], 70.6 \%$ $[n=24]$, respectively) (Table 1). All studied variables showed no significant association with Giardia infection or detected Giardia assemblage (Table 2).

Table 1: Diagnostic yield of nPCR and sequencing among microscopically positive samples.

nPCR

\begin{tabular}{|c|c|c|c|c|c|c|}
\hline & \multicolumn{6}{|c|}{ nPCR } \\
\hline & \multicolumn{4}{|c|}{ Positive $(n=36)$} & \multirow[t]{3}{*}{ Negative } & \multirow{3}{*}{ Tota } \\
\hline & \multirow[t]{2}{*}{ Assemblage AII } & \multicolumn{3}{|c|}{ Assemblage B } & & \\
\hline & & BIII & BIV & Total & & \\
\hline Positive microscopy & 2 & 10 & 24 & 34 & 2 & 38 \\
\hline
\end{tabular}


Table 2: Demographic and clinical data of the studied children positive by $\mathrm{nPCR}(\mathrm{n}=36)$.

\begin{tabular}{|c|c|c|c|}
\hline \multicolumn{2}{|c|}{ Variables } & \multirow[t]{2}{*}{ n (\%) } & \multirow[t]{2}{*}{$P$ value } \\
\hline Age group (years old & & & \\
\hline$>2-6$ & & $16(44.5)$ & 0.96 \\
\hline$>6-12$ & & $20(55.5)$ & \\
\hline \multicolumn{4}{|l|}{ Sex } \\
\hline Male & & $24(66.7)$ & 0.33 \\
\hline Female & & $12(33.3)$ & \\
\hline \multirow{4}{*}{ Clinical examination } & Abdominal cramps & $13(36.1)$ & 0.27 \\
\hline & Flatulence & $5(13.9)$ & 0.56 \\
\hline & Diarrhea & $5(13.9)$ & 0.56 \\
\hline & Vomiting & $7(19.4)$ & 0.47 \\
\hline \multirow{3}{*}{ Stool consistency } & Loose & $11(30.6)$ & \multirow{3}{*}{0.23} \\
\hline & Soft & $15(41.7)$ & \\
\hline & Greasy & $10(27.8)$ & \\
\hline
\end{tabular}

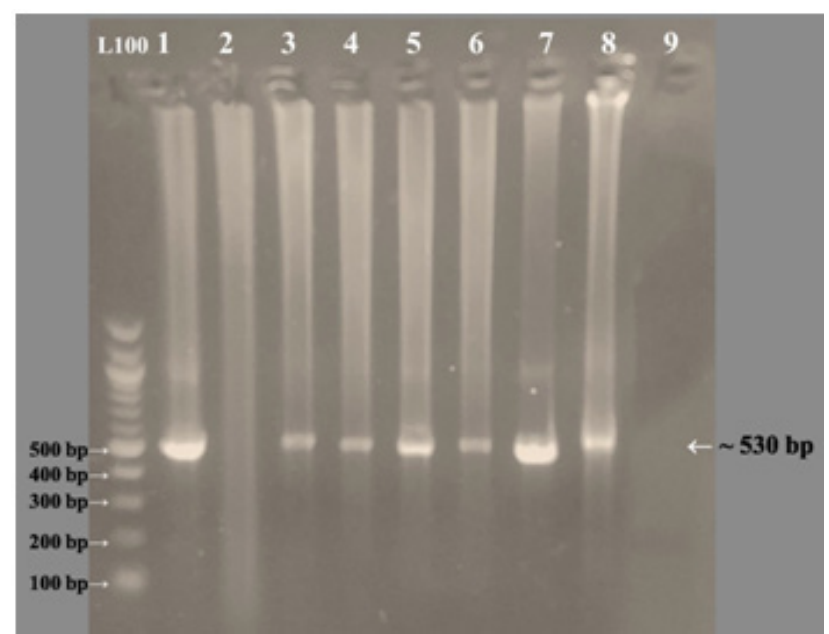

Fig. 1: Agarose gel stained with ethidium bromide for Giardia nPCR product of study samples targeting tpi gene: lane L100 Molecular weight marker (100 bp), lane 1 is positive control at $530 \mathrm{bp}$, lane 2 is negative control, lanes 3-8 are positive specimens, lane 9 is a negative specimen.

\section{DISCUSSION}

Diarrheal disease is one of the worldwide leading causes of children morbidity and mortality with 2 billion cases yearly ${ }^{[18]}$. Giardiasis causes most of diarrhea cases worldwide ${ }^{[19]}$. G. intestinalis was detected in $30.2 \%$ of diarrhoeic children from Zagazig city in our study. Phylogenetically, within genus Giardia there are 6 species, amongst which only $G$. intestinalis has been documented as infecting humans ${ }^{[11,13]}$. Based on molecular analyses, 8 assemblages A-H of $G$. intestinalis species were recognized; assemblages $\mathrm{A}$ and $\mathrm{B}$ infect mammals including humans, while, assemblages
$\mathrm{C}-\mathrm{H}$ are zoonotic and more host specific ${ }^{[10,12]}$. Lebbad et al. ${ }^{[20]}$ reported that there is limited zoonotic transmission among human Giardia genotypes. Different loci on multiple genes have been targeted for $G$. intestinalis molecular sub-typing, including small subunit ribosomal RNA, $\beta$-giardin, glutamate dehydrogenase, elongation factor 1-alpha $(g d h), t p i$, GLORF-C4 and the inter-genomic rRNA spacer region ${ }^{[21]}$.

$\beta$-giardin gene was considered a target for the molecular detection of Giardia spp. as it is unique to Giardia ${ }^{[22]}$. Nevertheless, tpi gene is preferred by many studies due to its high genetic heterogenicity ${ }^{[14,23]}$. The ssrRNA gene is the least used because it lacks specificity ${ }^{[24,25]}$. Direct sequencing of an amplified DNA sequence remains the "gold standard" for accurate typing and sub-typing of Giardia $^{[26]}$.

Targeting the $g d h$ gene by PCR-RFLP revealed that assemblage AII was much higher than assemblage BIII in cases from Menofeya and Sharkia Governorates ${ }^{[27]}$. Also from Egypt, El Tantawy and Taman ${ }^{[15]}$, targeting the $t p i$ gene, reported $62.14 \%$ as assemblage $\mathrm{B}, 31.07 \%$ as $\mathrm{A}$, and mixed A and B in $2.91 \%$ with $3.88 \%$ of undetermined species. Hence with variable reports on prevalence, assemblage B seems to be the most prevailing assemblage for Giardia infections in Egypt as documented in many Egyptian studies in Cairo ${ }^{[2,28]}$, Kafr Elshiekh ${ }^{[29]}$, and Ismailia $^{[13,30]}$.

Our study revealed a much higher assemblage B predominance $(94.4 \%)$, with no association between $G$. intestinalis and the patient's demographic and clinical data. There continues to be controversial reports 
concerning correlation between Giardia assemblage (A or B) and clinical symptoms. Although there are reports on the lack of correlation between Giardia assemblage (A or B) and clinical symptoms ${ }^{[31,32]}$, a few studies report significant correlation ${ }^{[33-35]}$. In the report by El Tantawy and Taman ${ }^{[15]}$, the detection rate of assemblage B was higher in samples from children with persistent diarrhea, whereas assemblage A detection rate was higher in samples from acute diarrhea. Thus, we corroborate the report of Rafiei et $a l{ }^{[36]}$ on the need for more studies to understand these relations.

Giardia was the prevailing enteric pathogen (38/126 [30.2\%]) among our study group, indicating that physicians and public health professionals should consider Giardia in diarrhoeic children. Giardiasis seems to be endemic in Zagazig as none of the study population had travel history.

We amplified Giardia copro-DNA by nPCR for 36 of the 38 microscopically positive samples. Negativity of positive microscopic samples by PCR may be attributed to the different Giardia strains, which may include single-nucleotide polymorphisms, insertion-deletion, and rearrangements of chromosomes. The negative results could also be explained by the presence of inhibitors in stool that may affect the DNA amplification ${ }^{[37]}$.

In conclusion, $G$. intestinalis is the prevailing intestinal pathogen found in diarrhoeic Egyptian children, with a predominance of Giardia assemblage B. These findings necessitate physicians' attention when diagnosing diarrhoeic patients. Further genetic studies are needed, in Egypt and other endemic areas, targeting different genetic loci, with the inclusion of larger population samples. This will lead to a better understanding of the ecological and clinical impact of Giardia infection and its management and control.

Author contribution: All authors contributed equally in the work.

\section{REFERENCES}

1. Adam RD. Biology of Giardia lamblia. Clin Microbiol Rev, 2001; 14: 447-475.

2. Ismail MA, El-Akkad DM, Rizk EM, El-Askary HM, El-Badry AA. Molecular seasonality of Giardia lamblia in a cohort of Egyptian children: A circannual pattern. Parasitol Res, 2016; 115(11): 4221-4227.

3. Nematian J, Gholamrezanezhad A, Nematian E. Giardiasis and other intestinal parasitic infections in relation to anthropometric indicators of malnutrition: a large, population based survey of schoolchildren in Tehran. Ann Trop Med Parasitol, 2008; 102(3): 209-214.

4. Puebla LJ, Núñez FA, Fernández YA, Fraga J, Rivero LR, Millán IA, Valdes LA, et al. Correlation of
Giardia duodenalis assemblages with clinical and epidemiological data in Cuban children. Infect Genet Evol, 2014; 23: 7-12.

5. Tsourdi E, Heidrich FM, Winzer M, Röllig C, Kirsch $\mathrm{C}$, Meinel J, et al. An exotic cause of exudative enteropathy. Am J Case Rep, 2014; 15: 226-229.

6. Bonhomme J, Le Goff L, Lemée V, Gargala G, Ballet JJ, Favennec L. Limitations of tpi and $b g$ genes subgenotyping for characterization of human Giardia duodenalis isolates. Parasitol Int, 2011; 60(3): 327-330.

7. Eligio-García L, Cortes-Campos A, Cota-Guajardo S, Gaxiola S, Jiménez-Cardoso E. Frequency of Giardia intestinalis assemblages isolated from dogs and humans in a community from Culiacan, Sinaloa, Mexico using beta-giardin restriction gene. Vet Parasitol, 2008; 156(3-4): 205-209.

8. Fahmy HM, El-Serougi AO, El Deeb HK, Hussein HM, Abou-Seri HM, Klotz C, et al. Giardia duodenalis assemblages in Egyptian children with diarrhea. Eur J Clin Microbiol Infect Dis, 2015; 34(8): 1573-1581.

9. WHO 1987: Prevention and control of intestinal parasitic infections. WHO Technical Report Series, $379,1-47$

10. Cooper MA, Adam RD, Worobey M, Sterling CR. Population genetics provides evidence for recombination in Giardia. Curr Biol, 2007; 17: 1984-1988.

11. Lasek-Nesselquist E, Welch DM, Sogin ML. The identification of a new Giardia duodenalis assemblage in marine vertebrates and a preliminary analysis of $G$. dodenalis population biology in marine systems. Int J Parasitol, 2010; 40: 1063-1074.

12. Lebbad M, Mattsson JG, Christensson B, Ljungstrom B, Backhans A, Andersson JO, et al. From mouse to moose: multilocus genotyping of Giardia isolates from various animal species. Vet Parasitol, 2010; 168: 231-239.

13. Solaiman RH, Fuentes I, Rubio JM. Identification of a novel assemblage B subgenotype and a zoonotic assemblage in human isolates of Giardia intestinalis in Egypt. Parasitol Int, 2011; 60: 507-511.

14. Thompson RCA, Monis PT. Variation in Giardia: Implications for taxonomy and epidemiology. Adv Parasitol, 2004; 58: 69-137.

15. El Tantawy NL, Taman AI. The epidemiology of Giardia intestinalis assemblages A and B among 
Egyptian children with diarrhea: A PCR-RFLP-based approach. PUJ, 2014; 7: 104-109

16. Sulaiman IM, Fayer R, Bern C, Gilman RH, Trout JM, Schantz PM, et al. Triosephosphate isomerase gene characterization and potential zoonotic transmission of Giardia duodenalis. Emerg Infect Dis, 2003; 9(11): 1444-1452.

17. Chvallet M, Luche S, Rabilloud T. Silver staining of proteins in polyacrylamide gels. Nat Protocol, 2006; 1(4): 1852-1858.

18. WHO 2009: Diarrhoea disease. Fact sheet No. 330. Available at: http://www.who.int/mediacentre/ factsheets/fs330/en/index.html

19. Mahdy MAK, Surin J, Wan KL, Mohd-Adnan A, AlMekhlafi MS, Lim YA. Giardia intestinalis genotypes: Risk factors and correlation with clinical symptoms. Acta Trop, 2009; 112(1): 67-70.

20. Lebbad M, Petersson I, Karlsson L, Botero-Kleiven $\mathrm{S}$, Andersson JO, Svenungsson B, et al. Multilocus genotyping of human Giardia isolates suggests limited zoonotic transmission and association between assemblage B and flatulence in children. PLoS Negl Trop Dis, 2011; 5: e1262.

21. Caccio SM, Ryan U. Molecular epidemiology of giardiasis. Mol Biochem Parasitol, 2008; 160: 75-80.

22. Caccio, SM, De Giacomo M, Pozio E. Sequence analysis of the $\beta$-giardin gene and development of a polymerase chain reaction-restriction fragment length polymorphism assay to genotype Giardia duodenalis cysts from human faecal samples. Int J Parasitol, 2002; 32: 1023-1030.

23. Huey CS, Mahdy MAK, Al-Mekhlafi HM, Nasr NA, Lim YAL, Mahmud R. Multilocus genotyping of Giardia duodenalis in Malaysia. Infect Genet Evol, 2013; 14: 269-276.

24. Weiss JB, Vankeulen H, Nash TE. Classification of subgroups of Giardia lamblia based upon ribosomal RNA gene sequence using the polymerase chain reaction. Mol Biochem Parasitol, 1992; 54: 73-86.

25. Ghieth, MA, Kotb MA, Abu-Sarea EY, El-Badry AA. Molecular detection of giardiasis among children at Cairo University Pediatrics Hospitals. J Parasit Dis, 2016; 40(4):1470-1474.

26. Geurden T, Levecke B, Caccio SM, Visser A, De Groote G, Casaert S. et al. Multilocus genotyping of Cryptosporidium and Giardia in non-outbreak related cases of diarrhoea in human patients in Belgium. Parasitology, 2009; 136: 1161-1168.
27. Sadek GS, El-Settawy MA, Soha A, Nasr SA. Genotypic characterization of Giardia duodenalis in children in Menoufiya and Sharkiya governorates, Egypt. Life Sci J, 2013; 10(1): 4006-4015.

28. Ghieth MA, El-Badry AA, Abu-Sarea EY, Abdel Gawad SS, Elsharkawy MM. Genotypic analysis of Giardia duodenalis in children at Egypt. Comp Clin Pathol, 2016; 25(6): 1241-1246.

29. Amer SE. Genotypic and phylogenetic characterization of Giardia intestinalis from human and dairy cattle in Kafr El Sheikh Governorate, Egypt. J Egypt Soc Parasitol, 2013; 43(1): 133-46.

30. Helmy YA, Krucken J, Nockler K, SamsonHimmelstjerna GV, Zessin KH. Comparison between two commercially available serological tests and polymerase chain reaction in the diagnosis of Cryptosporidium in animals and diarrhoeic children. Parasitol Res, 2014;113(1): 211-216.

31. Kohli A, Bushin OY, Pinkerton RC, Houpt E, Newman $\mathrm{RD}$, Sears CL, et al. G. duodenalis assemblage, clinical presentation and markers of intestinal inflammation in Brazilian children. Trans R Soc Trop Med Hyg, 2008; 102: 718-725.

32. Ajjampur SSR, Sankaran P, Kannan A, Sathyakumar $\mathrm{K}$, Sarkar R, Gladstone B, et al. G. duodenalis assemblages associated with diarrhea in children in south India identified by PCR-RFLP. Am J Trop Med, 2009; 80: 16-19.

33. Read C, Walters J, Robertson ID, Thompson RCA. Correlation between genotype Giardia duodenalis and diarrhoea. Int J Parasitol, 2002; 32: 229-231.

34. Cordon PG, Saldon OCP, Vasquezas VF, Soto JR, Bordes LS, Moreno MS, et al. Prevalence of enteroparasites and genotyping of $G$. duodenalis in Peruvian children. Parasitol Res, 2008; 103: 459-465.

35. Etemadi S, Zia-Ali N, Babaei Z, Fasihi-Harandi M, Zia-Ali A, Salari Z, et al. The correlation between clinical signs and genotypes of $G$. duodenalis isolated from patients with gardiasis in Kerman City. J Kerman Univ Med Sci, 2011: 18: 330-338.

36. Rafiei A, Roointan SE, Samarbafzadeh RA, Shayesteh AA, Shamsizadeh A, Borujeni PM. Investigation of possible correlation between Giardia duodenalis genotypes and clinical symptoms in Southwest of Iran. Iranian J Parasitol, 2013; 8(3): 389-395.

37. Abbaszadegan MR, Velayati A, Tavasoli A, Ryu H. Rapid DNA extraction protocol from stool suitable for molecular genetic diagnosis of colon cancer. IBJ, 2007; 11: 203-208. 